1. FCPS, MCE, FRCOG,

Fellowship in RE

Principal

Ameer ud Din Medical College/

PGMI

2. MBBS, M.Phil Physiology

Demonstrator Physiology

King Edward Medical University Lahore.

3. M.Phil Physiology

Professor Physiology

Continental Medical College.

4. M.Phil Physiology

Associate Professor

Department of Physiology

Rahbar Medical and Dental College

Lahore.

5. B.sc, MBBS, M.Phil

Assistant Professor Physiology

CMH LMC \& IOD (NUMS) Lahore.

6. M.Phil Physiology

Department of Physiology

Aziz Fatimah Medical \&

Dental College Faisalabad.

Correspondence Address:

Prof. Dr. Sardar Muhammad Al-Fareed

Zafar

Principal

Ameer ud Din Medical College/PGMI.

alfareedivf@hotmail.com

Article received on:

15/05/2019

Accepted for publication:

10/08/2019

Received after proof reading:

30/09/2019

\section{IMPACT OF BMI ON SERUM URIC ACID LEVELS IN FEMALES IN LOCAL POPULATION.}

\begin{abstract}
Sardar Muhammad AI-Fareed Zafar ${ }^{1}$, Rahat Naseem², Samia Jawed ${ }^{3}$, Saima Mukhtar ${ }^{4}$, Farhat ljaz
\end{abstract} Benash Altaf ${ }^{6}$

ABSTRACT: Body mass index is the fat content of body whereas hyperuricemia is the condition when serum uric acid level crosses the optimum normal level. Increase in BMI may influence serum uric acid. Objective: To find out the relationship of BMI with serum uric acid level in local population. Study Design: Cross sectional study. Setting: Lady Aitchison hospital Lahore. Period: March 2017- August 2017. Material and Methods: Written informed consent was taken prior to data collection. Detailed history was asked and weight in kilograms and height in meters was noted. Body mass index was calculated. Uric acid was measured by uricase method after taking $1 \mathrm{ml}$ venous blood under aseptic measures. Results: Body mass index and serum uric acid of the subjects were compared with the standard values that were $24.99 \mathrm{~kg} / \mathrm{m}^{2}$ and $5.7 \mathrm{mg} /$ $\mathrm{dl}$ and statistical analysis showed a significant difference (p-0.023 and p-0.000) respectively. Simple linear regression revealed 0.391 units change in serum uric acid level with one unit change in BMI. Conclusion: Serum uric acid increased with increase in BMI.

Key words: $\quad$ Body Mass Index, Hyperuricemia, Serum Uric Acid.

Article Citation: Zafar SMA, Naseem R, Jawed S, Mukhtar S, ljaz F, Altaf B. Impact of BMI on serum uric acid levels in females in local population. Professional Med J 2019; 26(10):1733-1737. DOI: 10.29309/TPMJ/2019.26.10.3721

\section{INTRODUCTION}

Body Mass Index is an easy way to measure the fat content of the body. According to definition it is the weight in kilograms divided by the square of height in meters of an individual. ${ }^{1}$

World Health Organization adapted the cut off points of BMI less than 18.50 as underweight, $18.50-24.99$ as normal, $\geq 25.00$ as overweight and $\geq 30.00$ as obesity. ${ }^{1}$

Higher BMI is an important predictor which leads to hypertension, type II diabetes mellitus, cardiovascular diseases, cancer, metabolic syndrome and hyperuricemia. ${ }^{2}$

The production and metabolism of uric acid which is the end product of purine metabolism is a complex process involving hepatic production, renal and gastrointestinal excretion. Uric acid is produced both by exogenous and endogenous sources. Exogenous sources include dietary intake of protein, high fructose intake and alcohol consumption while endogenous source is from liver, muscle, vascular endothelium, intestines and kidneys. ${ }^{3}$ Kidneys are responsible for excreting around $60-70 \%$ whereas intestine is responsible for excreting rest of the uric acid. ${ }^{4}$ Hyperuricemia is the condition which occurs when the serum uric acid crosses the normal levels of $2.5-5.7$ $\mathrm{mg} / \mathrm{dL}$ in females and $3.5-7.0 \mathrm{mg} / \mathrm{dL}$ in males. $^{5}$ It happens to occur whenever there is either increased production or decreased excretion of uric acid.

Hyperuricemia is itself a risk factor for various life threatening conditions like diabetes mellitus, metabolic syndrome, gout and hypertension. ${ }^{6}$ It does so because reactive oxygen species are produced in the process of catalysis of purine metabolism by xanthine oxidase. 
For the last 40 years, the prevalence of hyperuricemia is gradually increasing. It is observed as $21 \%$ in United States general population $^{7}$, whereas it is still higher as $52 \%$ in east Asia. ${ }^{8}$

Experimentally it is observed by different researchers that the deranged levels of serum uric acid may take part directly or indirectly in the development and/or progression of these diseases. ${ }^{6}$

Besides other risk factors of hyperuricemia like dyslipidemia, use of diuretics, renal insufficiency, alcohol intake, BMI is directly and independently related to serum uric acid as increased weight or obesity leads to overproduction or under excretion of uric acid so leading to hyperuricemia. ${ }^{9}$ Moreover the reduction in weight and so in $\mathrm{BMI}$ is considered as the non medical way of treatment of hyperuricemia in men and postmenopausal women. ${ }^{10}$

This study will in turn help the clinicians to screen the patients of hyperuricemia at risk so as to decrease the morbidity and mortality related to the outcomes of hyperuricemia.

\section{MATERIALS AND METHODS}

This cross sectional study was carried out after approval from hospital and ethical committee. 134 females who fulfilled the criteria were taken from outpatient department of Lady Aitchison hospital Lahore. Written informed consent was taken prior to data collection. By using 5\% level of significance, $95 \%$ confidence level, $90 \%$ power of test for expected percentage of uric acid level, 134 females were enrolled. Detailed history was taken from the participants. Participant's age, height and weight were recorded. Body mass index was calculated by using formula:

$\mathrm{BMI}=$ Weight in $\mathrm{kg} /$ height in meter $^{2}$

Blood sampling was done under aseptic measures. Centrifugation was done and serum samples were measured for serum uric acids by uricase method. Cups were numbered and stored in freezer at $-70^{\circ}$.
Data was analyzed by SPSS version 21. Simple regression technique was used to predict the relationship of serum uric acid and Body mass index. $p$-value $\leq 0.05$ was taken as significant.

\section{RESULTS}

Our study was comprised of total 134 females of age ranged from 20 to 72 years. Minimum age was 20 years and maximum was 72 years with mean of 44.6years.We found a significant difference in the Body Mass Index of the patient covered in the study with the standard value of BMI i.e. 24.99 (Table-I). We also found that there is a significant difference in Serum Uric Acid of the patient covered in the study with the standard value of Serum Uric Acid i.e. 5.7(Table-II).

Moreover, we observed a linear relationship between Serum Uric Acid and BMI. One unit change in BMI will impact by 0.391 on the serum uric acid. The results also witnessed that the linear relationship between serum uric acid and $\mathrm{BMI}$ is significant as suggested by the P-value in the table-III.

\begin{tabular}{|c|c|c|c|}
\hline \multicolumn{4}{|c|}{ One-Sample Test } \\
\hline & \multicolumn{3}{|c|}{ Test Value $=24.9$} \\
\hline & $\mathbf{T}$ & \multicolumn{2}{|r|}{ P-Value } \\
\hline $\mathrm{BMI}$ & 2.309 & \multicolumn{2}{|r|}{.023} \\
\hline \multicolumn{4}{|c|}{ Table-I. Mean testing of BMI } \\
\hline \multicolumn{4}{|c|}{ One-Sample Test } \\
\hline & \multicolumn{3}{|c|}{ Test Value $=5.7$} \\
\hline & \multicolumn{2}{|l|}{$\mathbf{T}$} & P-Value \\
\hline Serum uric acid & \multicolumn{2}{|c|}{-5.483} & .000 \\
\hline \multicolumn{4}{|c|}{ Table-II. Mean testing of serum uric acid } \\
\hline \multirow{2}{*}{ Model } & Coefficients & \multirow[t]{2}{*}{ T-Value } & P-Value \\
\hline & B & & \\
\hline (Constant) & -4.771 & -5.211 & .000 \\
\hline BMI & .391 & 10.857 & .000 \\
\hline \multicolumn{4}{|c|}{ Table-III } \\
\hline
\end{tabular}

Below chart shows that residual follow the normal distribution which is the main assumption of the simple linear regression. 


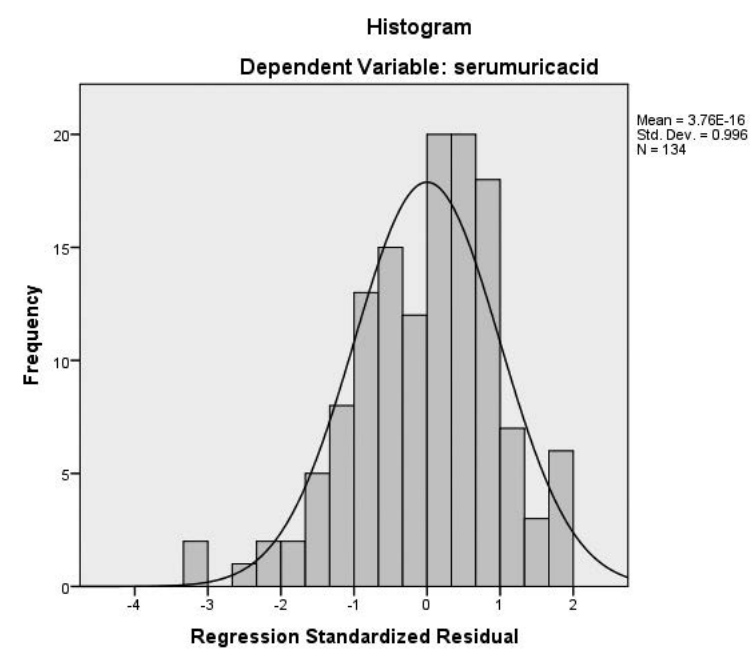

Normal P-P Plot of Regression Standardized Residual Dependent Variable: serumuricacid

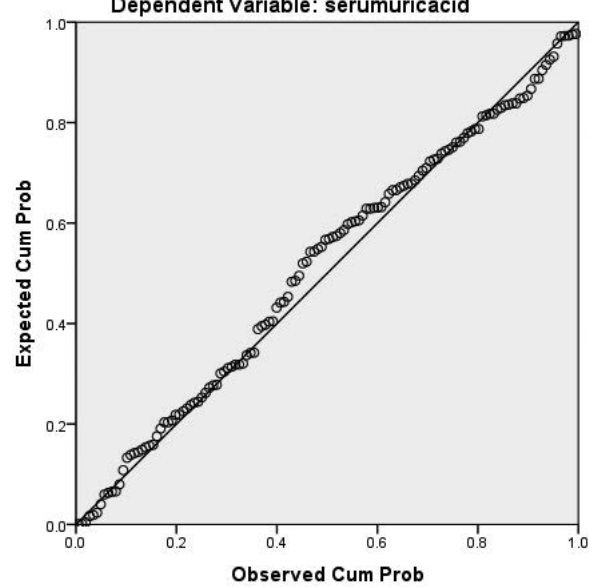

DISCUSSION

In this cross sectional study of 134 females of ages ranging from 20-72 years, $\mathrm{BMI}$ was found to be significantly associated with serum uric acid. It has been observed that with a unit increase in BMI, there is an increase up to 0.391 units in serum uric acid levels.

Previous studies corroborate our study as well in which the researchers supported the hypothesis that serum uric acid is significantly raised with rise in Body mass index. Various studies depict a parallel correlation between increase serum uric acid levels and the obesity. ${ }^{11,12}$

Another study by Palmer $\mathrm{T} M$ et al. showed a decrease in serum uric acid by reducing Body mass index. ${ }^{13}$ Similar kind of information was also stated by Ischizaka in Japanese population and an increase in serum uric acid was noted with increase in Body mass index after a follow up of 2 years in 3153 participants. ${ }^{10}$ Choi $\mathrm{H}$. K. and his colleagues found $39 \%$ reduction in in the risk of gout by decreasing weight nearly 10 pounds or little more. ${ }^{9}$

As far as the mechanism for the increase in serum uric acid in patients with higher Body mass index, Tsushima observed that adipose tissue of obese individuals secrete uric acid and is responsible for overproduction type of hyperuricemia. ${ }^{14}$

De Oliveria et al. found that there is a higher possibility of increased serum uric acid when $\mathrm{BMI}$ is equal or greater than $25 \mathrm{~kg} / \mathrm{m}^{2} .^{15}$ Serum uric acid and BMI are found to be changed longitudinally with advancing age. ${ }^{16}$

A cross sectional study by $\mathrm{T}$. Kentaro with his colleagues found a direct relationship between $\mathrm{BMI}$ and serum uric acid in monozygotic and dizogotic twins ${ }^{2}$. Hyon K. Choi observed a graded correlation of uric acid with $\mathrm{BMI}$ and when $\mathrm{BMI}$ is reduced by reducing high calorie diet, symptoms and signs of gout are also improved. ${ }^{9}$

B. Grgiel - Gorniak with his colleagues stated that the females with serum uric acid $\geq 4 \mathrm{mg} / \mathrm{dL}$ were observed to be having higher $\mathrm{BMI}$ and the linear regression model further documented that the group containing $\mathrm{BMI} \geq 25 \mathrm{~kg} / \mathrm{m}^{2}$ and blood glucose $\geq 100 \mathrm{mg} / \mathrm{dL}$ has the increased risk of increasing serum uric acid up to 4 times ( $p$-value $=0.0009) \cdot{ }^{17}$

K. Sunil et al. when compared the serum uric acid in pre and postmenopausal women found higher serum uric acid in postmenopausal women who develop hypreuricemia had higher BMI. ${ }^{18}$ $\mathrm{N}$. Hariong et al. found strongest relationship between hyperuricemic group and BMI when they studied Chinese population to find the prevalence of hyperuricemia in both men and women. ${ }^{19}$

Consistent to above studies $\mathrm{C}$. Jiunn-Horng et al. also found that $\mathrm{BMI} \geq 27 \mathrm{~kg} / \mathrm{m}^{2}$ in women may potentiate the effect in the gout development. ${ }^{20}$ 
Almost all of the studies mentioned above are supporting our study that increase in BMI causes increase in serum uric acid. Yet, most of them did not comment on the impact of change in BMI on serum uric acid whereas our study filled this deficiency. So, by controlling the body weight according to the height of the individual, to maintain BMI, can reduce the risk of developing hyperuricemia and related comorbidities. However, present study focused only the women, so other studies considering both genders should be conducted in local population as well.

\section{CONCLUSION}

Our study showed a significant effect of BMI on serum uric acid. We further used simple linear regression to see the impact of $\mathrm{BMI}$ on serum uric acid and found that with one unit change in BMI, there is 0.391 units change in serum uric acid in females.

\section{Copyright(C 10 August, 2019.}

\section{REFERENCES}

1. World Health Organization. WHO global database: BMI classification. [updated 2016; Accessed 2016] Available from: http://apps.who.int/bmi/index.jsp.

2. Tanaka K, Ogata S, Tanaka H, Omura K, Honda C, Hayakawa $K$. The relationship between body mass index and uric acid: A study on Japanese adult twins. Environ. Health Prev. Med. 2015; 20(5):347.

3. Chaudhary K, Malhotra K, Sowers J, Aroor A. Uric acidkey ingredient in the recipe for cardiorenal metabolic syndrome. Cardiorenal Med. 2013; 3(3):208-20.

4. Bobulescu IA, Moe OW. Renal transport of uric acid: Evolving concepts and uncertainties. Adv Chronic Kidney Dis. 2012; 19(6):358-71.

5. Merseburger AS, Kuczyk MA, Moul JW, (eds.) Urology at a glance. Germany: Springer. 2014; p.107.

6. Chen C, Lü JM, Yao Q. Hyperuricemia-Related Diseases and Xanthine Oxidoreductase (XOR) Inhibitors: An Overview. Med Sci Monit. 2016; 22(7):2501-12.

7. Zhu Y, Pandya BJ, Choi HK. Prevalence of gout and hyperuricemia in the US general population: The national health and nutrition examination survey 2007-2008. Arthritis Rheum. 2011; 63(10):3136-41.
8. Smith E, March L. Global prevalence of Hyperuricemia. A systematic review of population-based epidemiological studies. In Arthritis Rheumatol. 2015; 67(10):1-5.

9. Choi HK, Atkinson K, Karlson EW, Curhan G. Obesity, weight change, hypertension, diuretic use, and risk of gout in men: The health professionals follow-up study. Arch. Intern. Med. 2005; 165(7):742-8.

10. Ishizaka $\mathrm{N}$, Ishizaka $\mathrm{Y}$, Toda $\mathrm{A}$, Tani $\mathrm{M}$, Koike $\mathrm{K}$, Yamakado $M$, et al. Changes in waist circumference and body mass index in relation to changes in serum uric acid in Japanese individuals. J Rheumatol. 2010; $37(2): 410-6$.

11. Remedios $C$, Shah M, Bhasker AG, Lakdawala M. Hyperur- icemia: A reality in the Indian obese. Obes Surg. 2012; 22:945-8.

12. Liu L, Lou $S$, Xu K, Meng Z, Zhang Q, Song K. Relationship between lifestyle choices and hyperuricemia in Chinese men and women. Clin Rheumatol. 2013; 32:233-9.

13. Palmer T M, Nordestgaard B G, Benn M, Tybjærg Hansen A, Davey Smith G, Lawlor D, et al. Association of plasma uric acid with ischaemic heart disease and blood pressure: Mendelian randomization analysis of two large cohorts. BMJ. 2013; 347:f4262.

14. Tsushima $Y$, Nishizawa $H$, Tochino $Y$, Nakatsuji $H$, Sekimoto $\mathrm{R}$, Nagao $\mathrm{H}$, Shirakura $\mathrm{T}$, Kato $\mathrm{K}$, Imaizumi $\mathrm{K}$, Takahashi $\mathrm{H}$, Tamura M. Uric acid secretion from adipose tissue and its increase in obesity. Journal of Biological Chemistry. 2013 Sep 20;288(38):27138-49.

15. De Oliveira EP, Moreto F, Silveira LVDA, Burini RC. Dietary, anthropometric, and biochemical determinants of uric acid in free-living adults. Nutr J. 2013; 12:11.

16. Kuzuya M, Ando F, Iguchi A, Shimokata $H$. Effect of aging on serum uric acid levels: Longitudinal changes in a large Japanese population group. The J Gerontol. A Biol. Sci. Med. Sci. 2002; 57(10):M660-4.

17. Grygiel-Górniak B, Mosor M, Marcinkowska J, Przysławski J, Nowak J. Uric acid and obesity-related phenotypes in postmenopausal women. Mol Cell Biochem. 2018; 443(1-2):111-9.

18. Kumar S, Gupta R, Suppiah R. Gout in women: Differences in risk factors in young and older women. Ethnicity. 2012; 71:51-95.

19. Nan H, Qiao Q, Dong Y, Gao W, Tang B, Qian R, et al. The prevalence of hyperuricemia in a population of the coastal city of Qingdao, China. J. Rheumatol. 2006; 33(7):1346-50. 
20. Chen JH, Pan WH, Hsu CC, Yeh WT, Chuang SY, Chen PY, et al. Impact of obesity and hypertriglyceridemia on gout development with or without hyperuricemia: A prospective study. Arthritis Care Res. 2013; 65(1):133-40.

\begin{tabular}{|c|c|c|c|}
\hline \multicolumn{4}{|c|}{ AUTHORSHIP AND CONTRIBUTION DECLARATION } \\
\hline Sr. \# & Author-s Full Name & Contribution to the paper & Author's Signature \\
\hline 1 & $\begin{array}{l}\text { Sardar Muhammad } \\
\text { Al-Fareed Zafar }\end{array}$ & Article writing and proof reading. & \\
\hline 2 & Rahat Naseem & $\begin{array}{l}\text { Study design, collection of data, } \\
\text { Stats analysis, Article writing. }\end{array}$ & \\
\hline 3 & Samia Jawed & $\begin{array}{l}\text { Research idea, Literature search, } \\
\text { Final drafting. }\end{array}$ & uned \\
\hline 4 & Saima Mukhtar & $\begin{array}{l}\text { Literature search and Proof } \\
\text { reading. }\end{array}$ & \\
\hline 5 & Farhat ljaz & $\begin{array}{l}\text { Drafting, Proof reading and } \\
\text { references writing. }\end{array}$ & \\
\hline 6 & Benash Altaf & References wirting and formating. & \\
\hline
\end{tabular}

